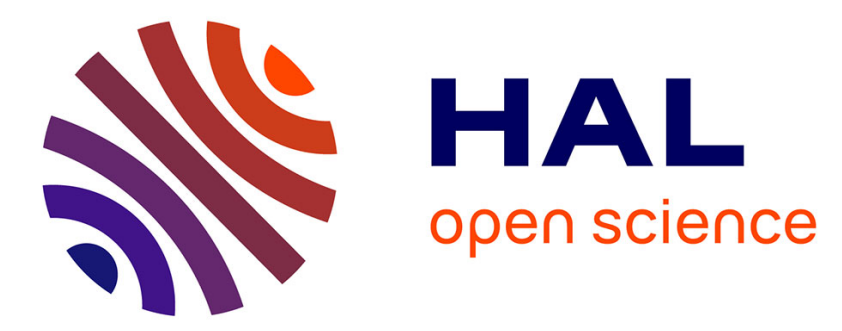

\title{
Bad times are not good times for revolutions: Collective deprivation and the mobilization level of French radical movements (1882-1980) \\ Simon Varaine
}

\section{- To cite this version:}

Simon Varaine. Bad times are not good times for revolutions: Collective deprivation and the mobilization level of French radical movements (1882-1980). Journal of Community and Applied Social Psychology, 2018, 28 (4), pp.258-271. 10.1002/casp.2356 . hal-01814504

\author{
HAL Id: hal-01814504 \\ https://hal.science/hal-01814504
}

Submitted on 13 Jun 2018

HAL is a multi-disciplinary open access archive for the deposit and dissemination of scientific research documents, whether they are published or not. The documents may come from teaching and research institutions in France or abroad, or from public or private research centers.
L'archive ouverte pluridisciplinaire HAL, est destinée au dépôt et à la diffusion de documents scientifiques de niveau recherche, publiés ou non, émanant des établissements d'enseignement et de recherche français ou étrangers, des laboratoires publics ou privés. 


\title{
Bad times aren't good times for revolutions
}

\section{Collective deprivation and the mobilization level of French radical movements (1882-1980)}

\author{
Simon Varaine \\ Univ. Grenoble Alpes, CNRS, Science Po Grenoble*, PACTE, 38000 Grenoble, France * \\ School of Political Studies Univ. Grenoble Alpes simon.varaine@etu-iepg.fr
}

Key words

collective action, deprivation, system justification, threat, terrorism

\section{Acknowledgements}

I would like to thank two anonymous reviewers for their insightful comments that greatly contributed to improving the final version of the paper. I would also like to thank Raul Magni-Berton, Claire Dupuy, Laurent Bègue, Sonja Zmerli and Céline Belot for their comments on earlier versions of the manuscript. This research is part of a Phd funded by the Communauté Université Grenoble Alpes. 


\begin{abstract}
Contrary to a popular belief, research has generally found no relationship between collective economic deprivation and the rise of radical political movements. On the other hand, various studies show that collective economic deprivation generates societal surges of conservatism. I therefore hypothesize that the absence of a relationship between collective deprivation and radical movements covers up opposite effects of collective deprivation depending on the ideology of radical movements: reactionary (i.e. conservative radical) movements should mobilize more in times of collective deprivation while revolutionary (i.e. progressive radical) movements should mobilize more in times of collective improvement. This paper tests this hypothesis via a new database measuring the level of mobilization of French radical organizations from 1882 to 1980 . Statistical analyses confirm that collective deprivation, operationalized by long-term economic recession and long-term growth of inequality, increases the mobilization of reactionary movements and decreases the mobilization of revolutionary movements. These results contradict the view that economic conditions have no role in triggering radical movements, and support recent development of system-justification theory implying that ideology matters in the explanation of collective action.
\end{abstract}

\title{
1. Introduction
}

A common assumption in most classical theories of revolts is that political radicalism is fuelled by economic misery. For some, collective deprivation, by revealing the system's contradictions, raises consciousness of the necessity for a revolution, and eventually leads to the rise of insurgent movements (Marx \& Engels, 2002). For others, collective deprivation, by frustrating people's expectations, generates anger, which eventually translates into political violence (Gurr, 2015). For still others, collective deprivation facilitates the recruitment of radical activists by reducing the cost of quitting economically productive occupations (Collier \& Hoeffler, 1998). However, an overview of empirical research does not support this 
common prediction: studies find that collective deprivation either has a small or nonsignificant effect on radicalism, which leads to the conclusion that collective deprivation has no substantive explanatory power to account for the rise of radical movements (Krueger, 2007, Krieger \& Meierrieks, 2011, Piazza, 2006).

On the other hand, there is a large amount of evidence which shows that collective economic deprivation generates surges of political conservatism (Sales, 1972, Sales, 1973, Doty, Peterson \& Winter, 1991, Feldman \& Stenner, 1997, Onraet, Van Hiel \& Cornelis, 2013a, Onraet, Van Hiel, Dhont \& Pattyn, 2013b, Miller, 2017, Rickert, 1998, Funke, Schularick \& Trebesch, 2016), suggesting that such conditions should be especially conducive to conservative radical movements. Based on a system-justification approach to collective action (Jost, Becker, Osborne \& Badaan, 2017), I therefore hypothesize that collective deprivation affects radical movements' mobilization differently depending on their ideology: reactionary (i.e. conservative radical) movements should mobilize more during times of collective deprivation, whilst revolutionary (i.e. progressive radical) movements should mobilize more during times of collective improvement.

Such differing impacts caused by collective deprivation help to shed light on persistent empirical puzzles. Firstly, this would explain the absence of a general effect of collective deprivation on radical movements, which may be due to the addition of sizeable inverted effects depending on the ideological orientation of these movements. Secondly, this hypothesis would chime with global historical trends in the orientation of terrorist movements (Shughart, 2006): whilst mainly of a left-wing revolutionary outlook in the late 1960s and 1970s, after periods of economic improvement, terrorism has undergone a reactionary shift since the 1990s, being mostly formed from Islamist and right-wing ideologies, in the aftermath of less prosperous economic times. 
In this paper, I provide the first empirical test of this hypothesis using new data on the mobilization level of French radical social movement organizations between 1882 and 1980. I use two indicators of collective economic deprivation for the majority of the French population: the long-term growth of GDP, and the long-term evolution of inequality. As expected, the results show that collective economic deprivation has no general effect on the mobilization level of radical organizations, while it has significant opposite effects on the level of mobilization of reactionary versus revolutionary movements.

In the following section, I develop the literature on the respective effects of collective deprivation on radicalism and conservatism, and how system-justification theory allows these lines of research to be connected. In section three I detail my hypotheses. In section four, I introduce the data on French radical organizations, and my empirical strategy. I present the results in section five and discuss their implications in section six.

\section{Connecting two pieces of evidence about collective economic deprivation}

\subsection{Collective deprivation does not predict radicalism}

Political radicalism is commonly defined as the use of illegal means to achieve political changes (Moskalenko \& McCauley, 2009, Tausch et al., 2011) - which includes violent action by terrorist groups. Empirical research on collective deprivation has mainly centred around the relationship between aggregated measures of political radicalism - in particular, the number of terrorist incidents and casualties - and country-level indicators of economic deprivation - such as economic growth and level of inequality. While some studies find that countries facing economic recession engender more terrorist activity (Kis-Katos, Liebert \& Schulze, 2011, Caruso \& Schneider, 2011), studies on different samples and operationalization do not replicate this finding (Piazza, 2006, Kurrild-Klitgaard, Justesen \& Klemmensen, 2006, Krueger, 2007). Besides, economic inequality mostly does not show a significant relationship with terrorism (Abadie, 2006, Piazza, 2006, Kurrild-Klitgaard et al., 
2006). Summing up these inconsistent results, Krueger affirms that there is "little support for the view that economic circumstances are an important cause of participation in terrorism" (2007:6).

\subsection{Collective deprivation predicts conservatism}

In contrast with research on radicalism, there is consistent evidence which indicates that collective economic deprivation increases political conservatism, defined as a social cognition valuing resistance to social change culturally and acceptance of inequality economically (Jost, Glaser, Kruglanski \& Sulloway, 2003). Indeed, indicators of societal threat - including economic recession, inflation and unemployment - correlate with societal expressions of authoritarianism (Sales, 1972, Sales 1973, Doty et al., 1991, Funke et al., 2016), capturing the cultural component of conservatism. Studies on international surveys similarly reveal that threat-indicators including measures of collective deprivation increase both cultural and economic conservative attitudes (Onraet et al., 2013a) and that increasing inequality is related to heightened authoritarian attitudes (Miller, 2017). Perceived collective economic threat is also related to authoritarianism (Rickert 1998, Feldman \& Stenner 1997, Onraet et al., 2013b). All in all, the evidence linking collective deprivation to the cultural component of conservatism is robust, while it is less unequivocal regarding its economic component (Onraet et al., 2013b). Indeed, an experimental study (Duckitt \& Fischer, 2003) has shown that people confronted with a threatening scenario involving the socio-economic decline of their country displayed higher authoritarianism compared to a control group, while the manipulation only indirectly affected their social dominance, capturing the economic component of conservatism.

The underlying mechanism presumably comes from the more general effect of threat and uncertainty on conservatism. Indeed, there is a huge amount of evidence indicating that situational and chronic needs for security and certainty relate strongly to conservative beliefs 
(see Jost, 2017 for a recent review), because valuing traditional social arrangements provides unambiguous responses to threat and uncertainty (Jost et al., 2003). Collective deprivation is likely to induce threat and uncertainty. Indeed, Duckitt and Fischer (2003) found that the effect of the declining socio-economic scenario on authoritarianism was entirely mediated by the perception that the world is dangerous, and Rieger, Frisclich and Bente (2017) found that a scenario of socio-economic decline for the in-group significantly increased uncertainty.

\subsection{Making the connection: a system-justification approach to collective action}

Based on the preceding results, Jost et al. (2017) recently proposed integrating ideology into the socio-psychological framework of collective action. Jost et al. emphasize that both participation in collective action and its ideological orientation should critically depend upon the factors that have proven to affect conservatism - including the need to manage threat and uncertainty. Thus, chronic and situational threat and uncertainty, through increasing systemjustification, should increase participation in system-supportive (conservative) protest while undermining participation in system-challenging (progressive) protests. This framework is consistent with recent results showing that uncertainty and threat specifically increase rightwing oriented radicalism: Pauwels and Heylen (2017) found that perceived in-group threat, through increasing authoritarianism, was related to participation in right-wing violence in a sample of young Belgians; and recent studies show that existential threat (Frischlich, Rieger, Hein \& Bente, 2015) and uncertainty (Rieger et al., 2017) increase interest in right-wing extremist groups' propaganda.

Based on system-justification theory, I therefore hypothesize that collective economic deprivation, by increasing threat and uncertainty, is likely to affect radicalism in the following way: collective deprivation should reduce participation in progressive radical movements and increase participation in conservative radical movements, which would be compatible with the absence of a general effect of collective deprivation on radicalism. 
One may wonder whether a "conservative radical" movement is an oxymoron? Indeed, it could be argued that radical movements are, by definition, progressive, inasmuch as they seek to achieve some political change: from this perspective, a radical conservative movement is a nonsense. Nonetheless, I argue that a radical movement may be classified as conservative inasmuch as it promotes societal changes in order to restore a traditional order. As previous studies (Parker \& Barreto, 2014, Lipset \& Raab, 1970), I call these reactionary movements. Conversely, I call radical progressive movements, which advocate for societal changes in order to put an end to a traditional order, revolutionary movements. Note that these concepts focus on the cultural (pro-tradition) component of conservatism, leaving aside its economic component, because the latter seems only indirectly related to collective deprivation (Duckitt \& Fischer, 2003).

\section{Summary of hypotheses and research overview}

Based on the previous discussion, this paper aims to test the following hypotheses:

- H1: long-term collective deprivation does not affect the mobilization level of radical movements.

- H2: ideology moderates the relationship between long-term collective deprivation and the mobilization level of radical movements:

- H2a: long-term collective deprivation increases the mobilization level of reactionary movements.

○ H2b: long-term collective deprivation decreases the mobilization level of revolutionary movements.

Before detailing the empirical analysis, I shall provide some clarification about my hypotheses. Firstly, what do I mean by collective deprivation precisely? As studies discussed in the preceding section, I am basically referring to the evolution of both the absolute and relative level of wealth of the majority in a given society, that is the overall level of wealth 
per capita and the level of inequality. Secondly, why do I specify "long-term" collective deprivation? The reason is that conjuncture variations should not seriously alter people's environment and expectations and thus their experience of threat and uncertainty. Actually, studies which establish a link between economic threat and societal expressions of authoritarianism generally compare non-threatening periods to depressions lasting several years (Sales, 1972, 1973, Doty et al., 1991, Funke et al., 2016), and the experimental scenario used by Duckitt and Fischer (2003) depicted a long-term (10 year) socio-economic decline. In the present study, I provide a first test of the hypotheses using a new dataset about the mobilization level of French radical social movement organizations from 1882 to 1980. I investigate whether the number of members in these organizations depends on the interaction between their ideological orientation - reactionary versus revolutionary - and indicators of long-term collective deprivation. The following section details the rationale of this case selection and my empirical strategy.

\section{Method}

\subsection{Case selection}

I selected the French case and the study period to ensure the concomitant presence of both reactionary and revolutionary national-level radical organisations and to control for relevant variables. Indeed, some concurrence among radical organizations is necessary to ensure that I measure the resonance of one radical ideology instead of some general radical affinity. Moreover, the French metropolitan case (excluding colonies and overseas territories) during this period allows for keeping relatively constant various factors which affect the use of radical actions, such as the decentralization level, i.e. the existence of local centers of decision-making (Dreher \& Fischer, 2011), and the state capacity, i.e. the share of resources controlled by the government (Li \& Schaub, 2004). 
I chose the starting year - 1882 - because of the re-formation of both reactionary and revolutionary organizations at the national level. On the revolutionary side, the 1879 and 1880 amnesty laws allowed for the coming back of activists who were deported after the Commune. Whilst union chambers - ancestries of the Confédération Générale du Travail grew in size after 1871, pursuing a moderate agenda, a few started to radicalize in 1878 by adopting a collectivist ideology and defying prefectural decisions. Moreover, the first highscale anarchist attack occurred in 1882 in Lyon at the "Assomoir" and the anarchist movement may be estimated at this time to gather a thousand activists. On the reactionary side, the first French nationalist and authoritarian mass movement carrying out street demonstrations and activism - the Ligue des Patriotes - was created in 1882.

I stopped the study period in 1980 because important changes in radical social movement organizations would require further investigation. For instance, most of the radical events recorded during the 1980s are related to regionalist groups, which are hard to qualify on the revolutionary-reactionary distinction without systematic content-analysis methods. I excluded organizations that were directly linked to the First and Second World War and to the Algerian Independence War since the level of state repression, the mobilization into war and the conflict escalation among radical organizations were aberrant in comparison to the rest of the study period.

\subsection{Database constitution and analysis}

\subsubsection{Sources selection: historical research}

There are several ways to gather systematic information on social movements such as analysing public records or press contents. Nevertheless, these types of sources, while useful for recording protest events, do not systematically contain information on the mobilization level and ideological position of social movement organizations. To combine these three pieces of information, I chose to use historical research as a source of data. Given that it was 
impossible to exhaustively review historical research for the study period, I proceeded by a snowball sampling of documents in a defined period of three months, starting with a general book on the history of French social movements (Pigenet \& Tartakowsky, 2014). At the end of this phase, I had analysed 118 documents.

Using historical research as a source of generalizability implies potential biases that I tried to neutralize via the coding procedure and method of analysis. I distinguish two types of biases: representativeness and reliability problems. Representativeness bias means that the sources under or over-represent some kind of organizations compared with their frequency in the real population, leading to incorrect generalization. To address this issue, I controlled for variables that could account for systematic biased representation in the historical sources such as the historical period, the organisations' ideological orientation and organization type. Reliability bias means that the quality of information differs from one group to another, leading to an under or over-estimation of their characteristics, especially their number of adherents and level of radicalization. In the next section I explain the method I used to deal with this issue.

\subsubsection{Organization-level variables}

The unit of observation is a radical organization in a given year. The minimal requirement for social movement organizations to be considered as radical and therefore included in the database is if the sources indicate that 1) they promoted a societal (not only sectorial) change and 2) they have ever used or promoted illegal protest activity through their discourse. Indeed, many observations would have been lost by limiting the sample to solely the years in which an organization actually engaged in/promoted radical activity. However, I also tested the statistical models under this constraint to check the robustness of the results on a narrower definition of radical organizations (see the online appendix).

Mobilization level. The dependent variable - the number of radical organization members has been coded thanks to the information provided by the sources. To ensure reliability, I 
generated a variable - source - indicating the origin of the information provided by the authors, in order to control for systematic misestimating due to some primary sources. As I obtained many punctual estimates, I calculated linear interpolations (or, if I had only one referring point, extrapolations) for the missing values. I obtained the number of members for 70 organizations, with a total of 715 observations. As the variable was not normally distributed $($ skewness $=4.10$, kurtosis $=26.71), \mathrm{I} \log$-transformed it $($ skewness $=-.55$, kurtosis $=2.52)$.

Ideology. Based on the analyses provided by my sources and their empirical material, I generated a binary variable indicating the organisations' ideology $(0=$ revolutionary, $1=$ reactionary). I defined an organization as reactionary if 1) it values a return to what it describes as a traditional way of life and 2) expresses a perception of societal decline. I defined an organization as revolutionary if 1) it values a change to what it describes as novelty and 2) criticizes the past social order. Of the 70 radical organizations for which I determined the number of adherents, I classified 36 as revolutionary, and 34 as reactionary (48\% of the 715 observations).

Radicalization. As the radicalization level of organizations greatly vary in my dataset - from political organizations that sometimes used non-violent illegal action to terrorist organizations - , I included measures of radicalization as controls in order to analyse the effect of collective deprivation on their mobilization level at a constant level of radicalization. To do this, I first created a set of dummy variables indicating whether the organization used specific types of action, targets and discourse during a given year. Following previous empirical studies on radicalism (Tausch et al., 2011; Moskalenko \& McCauley, 2009) I then applied a multidimensional analysis - here, a multiple correspondence analysis - on these variables, which yielded a radicalization dimension (explaining $14.62 \%$ of the variance). The dimension goes from relatively moderate illegal action and discourse to extreme illegal action and discourse, 
in line with Della Porta's (2006) assessment of the degree of radicalization by the magnitude, premeditation and targeting of political violence. From the coordinates of each dummy on this dimension, I generated two independent variables respectively indicating the degree of use of moderately radical and extremely radical repertories.

\subsubsection{Year-level variables}

Long-term collective deprivation. As explained in the previous section, I measured collective deprivation in a given year $\mathrm{t}$ by two indicators: the annual variation of the national wealth, captured by the growth in GDP per capita (The Maddison-Project, 2013) and the annual variation of inequality, captured by the variation in the share of the national wealth owned by the $10 \%$ richest (Piketty, 2013). As I am interested in the long-term collective deprivation experienced in a given year $\mathrm{t}$, I calculated the mean of these indicators between $\mathrm{t}$ and t-10 years. For example, for 1936, my two indicators respectively refer to the mean annual growth in GDP per capita between 1926 and 1936 and the mean annual growth of inequality between 1926 and 1936. Since I am agnostic on what long-term precisely means, I performed alternative models with other temporal specifications - between $\mathrm{t}$ and $\mathrm{t}-5$ years, between $t$ and $t-15$ years and between $t$ and $t-20$ years (see the online appendix) - to check the consistency of the results. I will accept my hypotheses if 1) I find a robust relationship in the expected direction for some temporal specifications and 2) do not find a robust opposite relationship in any of the other temporal specifications.

Control variables. I controlled for macro-level variables that have been proven relevant in previous studies: the level of democracy (Abadie, 2006), measured by the "polity index" (Polity IV, 2015), going from -10 (autocratic regime) to 10 (democratic regime); the unemployment rate (Caruso \& Schneider, 2011), which was 1-year lagged; and the population size (Kis-Katos et al., 2011, Krueger, 2007). I also controlled for the ideological position of the government, coded on a right-left scale from -2 (both government and assembly hold by 
right-wing parties) to 2 (both government and assembly hold by left-wing parties). Indeed, one can expect that revolutionary organizations are more appealing under a right wing administration (and conversely for reactionaries).

\section{Results}

In this section, I present the results of log-linear regression analyses of the mobilization level (number of members) of radical organizations. Firstly I provide general comments about the models, secondly I detail the main results about the relationship between the mobilization level of radical organizations and indicators of collective deprivation for the past 10 years, I then analyse the consistency of the findings across different temporal specifications and finally I check the robustness of the results based on a sub-sample of radical organizations and on sensitivity analyses.

\subsection{General comments}

I present the regression analyses in hierarchical steps in table 1 and in the tables of the online appendix. The first five steps include the independent variables of interest: model I only includes GDP growth and model II includes the interaction between this variable and the organizations' ideology; models III and IV perform the same test with the variation of inequality; and model V includes all those variables together. The last three steps include the control variables in distinct steps to test whether their inclusion affects the coefficients of the variables of interest: model VI includes the organisation-level control variables; model VII includes the year-level control variables; and model VII includes both organisation-level and year-level control variables. As the White's test detected some heteroscedasticity, I computed robust standard errors for the coefficients. To improve readability, in table 1 I do not detail estimates for the fixed effects of organization type, information source and decade (see the online appendix for these estimates). Note that the number of observations decreases from 
model II to III because the information on the share of national wealth owned by the richest $10 \%$ starts in 1908 , thus narrowing the sample.

\section{[Insert table 1 around here]}

Before detailing the results, I shall have a quick look at the control variables. Firstly, table 1 show interesting relationships between levels of radicalization and mobilization: the use of moderately radical repertories is positively related to the mobilization level $(\mathrm{p}<.01)$, while the use of extremely radical repertories displays an opposite relationship, albeit at a low level of significance $(\mathrm{p}<.10)$. This may be interpreted in line with research on protest cycles which shows that mobilization periods are related to the use of moderate means, whilst radicalization is more likely to occur during periods of demobilization (Della Porta, 2006). Besides, the year-level controls have non-significant or inconsistent effects on the level of mobilization of radical organizations across the models.

\subsection{Collective deprivation and mobilization level}

In line with $\mathrm{H} 1$, the results from table 1 show that indicators of collective deprivation do not have any general relationship with the mobilization level of radical organizations. Indeed, model I shows that growth of GDP over a period of 10 years does not significantly affect the mobilization level of radical organizations $(b=-.04, p=.423)$ and model III shows that a growth in inequality over 10 years does not affect the mobilization level either $(b=-.13$, $\mathrm{p}=.273)$.

In contrast, results from table 1 strongly support the hypothesis that collective deprivation affects the mobilization of radical organizations differently depending on their ideology $(\mathrm{H} 2)$. Indeed, in model II, the coefficient of the interaction term between the growth of GDP and the organizations' ideology $(b=-.21, p=.014)$ is significant and larger in absolute value than that of the main effect of the growth of GDP $(b=.07, p=.254)$. This indicates that the relationship between the economic growth over 10 years and the mobilization of organizations is opposite 
for reactionary organizations compared to revolutionaries. The negative sign of the coefficient is in line with H2a: the lower the economic growth for the past 10 years, the higher the mobilization of reactionary organizations. This result is confirmed when adding indicators of inequality (model V) and the control variables (models VI, VII and VIII).

The main effect of the growth of GDP over 10 years, which must be interpreted as its effect on the mobilization level of revolutionary organizations, is not significant in model II but attains significance in the subsequent models V to VIII. Analyses do not support the idea that this change in significance is due to collinearity issues, in particular between GDP growth and the growth of inequality: actually, these variables are not highly correlated $(r=.28)$, variance inflated factors yielded from model V are acceptable (mean VIF=2.8) and the coefficient remains significant when running models VI to VIII without including the growth of inequality. This rather supports the idea that, when taking into account relevant control variables, the past 10 years' economic growth is positively related to the mobilization level of revolutionary organizations, in line with $\mathrm{H} 2 \mathrm{~b}$.

With regard to the evolution of inequality, the estimates of all models in table 1 support $\mathrm{H} 2$. In model IV, the coefficient of the interaction between the evolution of inequality and ideology $(\mathrm{b}=.61, \mathrm{p}=.012)$ is positive, significant and larger in absolute value than the main effect of the evolution of inequality $(b=-.35, p=.016)$, which indicates that the higher the growth of inequality for the past 10 years the higher the mobilization level of reactionary organizations, in line with $\mathrm{H} 2 \mathrm{~b}$. Conversely, the coefficient of the main effect of the evolution of inequality is significantly negative: the higher the growth of inequality for 10 years the lower the mobilization level of revolutionary organizations, in line with $\mathrm{H} 2 \mathrm{~b}$. These coefficients remain significant and the interaction term larger in absolute value than the main effect in the subsequent models V to VIII, which confirms these opposite relationships. Note 
that the estimates for both the variations of GDP and inequality and their interaction with ideology are identical when mean centring the variables.

\subsection{Tests on different temporal specifications}

I applied similar regression models to other temporal specifications regarding the variables of interest: the growth of GDP and inequality for the past 5 years, 15 years and 20 years (see the online appendix). In line with $\mathrm{H} 1$, most of these alternative indicators of collective deprivation do not have a significant relationship with the mobilization level of radical organizations in general. When, in some cases, there is a general significant relationship between an indicator of collective deprivation and the mobilization level of radical organizations, the inclusion of the interaction effect indicates that the effect is in fact significantly different for revolutionary versus reactionary organizations. Besides, I find the expected differential effects of collective deprivation, similar to the one presented in table 1 , in other temporal specifications. Interestingly, the growth of the GDP per capita has the expected differential effect on the mobilization level of revolutionary versus reactionary organizations in middle-term specifications (when I specify the growth of GDP for the past 5 or 10 years), while it has either non-significant or inconsistent effects in the other specifications. In contrast, the growth of inequality has the expected differential effect in long-term specifications (when I specify the growth of inequality for the past 10,15 or 20 years), while it has either non-significant of inconsistent effects in the five years specification. This may be due to the fact that the societal consequences of GDP growth are more readily visible and may provoke social reactions faster than inequality, whose effects might emerge in a delayed and indirect manner.

\section{[Insert figure 1 and 2 around here]}

Based on these models, I calculated linear marginal effects to estimate, at average values for all other variables, the predicted level of mobilization of radical organizations across the 
distribution of the variables of interest (going from the mean - 2 standard deviations to the mean +2 standard deviations). Figures 1 and 2 plot these estimates and the corresponding confidence interval for the temporal specifications that produced the most salient results: the variation for 5 years of GDP (figure 1) and the variation for 15 years of the level of inequality (figure 2). These estimates clearly support $\mathrm{H} 2$, showing inverse relationships for revolutionary and reactionary organizations. The higher the GDP growth for the past 5 years, the higher the mobilization of revolutionary organizations and the lower the mobilization of reactionary organizations. The higher the increase of inequality for the past 15 years, the lower the level of mobilization of revolutionary organizations and the higher the level of mobilization of reactionary organizations.

\subsection{Robustness checks}

To check the robustness of the results, I first applied regression models to a more exclusive sample including only the years in which organizations actually engaged in radical action and/or discourse. The results are mostly similar to the general models (see the online appendix).

Secondly, I performed sensitivity analyses to check the robustness of the results when adding or removing independent variables from the models. Synthetic statistics from these sensitivity analyses for each temporal specification are presented in the online appendix. Confirming the previous results, the relationship between the growth of GDP and the mobilization of revolutionary versus reactionary organizations is strongly robust in the 5 years specification, less robust in the 10 years specification and not robust in the 15 and 20 years specification. Conversely, the relationship between the growth of inequality and the mobilization of revolutionary versus reactionary organizations is strongly robust in the 20 and 15 years specification, less robust in the 10 years specification and not robust in the 5 years specification. 
Finally, I tested models controlling for the one-year-delayed level of mobilization of radical organizations, as a highly conservative test. However, these models yielded mostly nonsignificant effects of both macro and micro variables. To sum up, evidence indicates that the robustness of the results is satisfactory.

\section{Discussion}

Whilst it is popularly assumed that political radicalism is fuelled by collective deprivation, empirical research has mostly rejected this idea and concluded that economic context plays a minor role with regard to the emergence of radical movements (Krueger, 2007, Krieger \& Meierrieks, 2011, Piazza, 2006). This paper challenges this conclusion. Based on systemjustification theory, I have proposed that collective deprivation in fact has a substantive effect on the rise of radical movements, but that the direction of this effect depends on their ideology. My empirical analyses of French radical organizations between 1882 and 1980 support this claim, demonstrating that opposing economic conditions are related to the mobilization of two distinct radical ideologies: reactionary ideologies mobilize during longterm episodes of economic deprivation, whereas revolutionary ideologies mobilize under periods of improving conditions.

\subsection{Theoretical implications}

These results have three main theoretical implications. Firstly, with regard to the literature on radicalization, this paper suggests that the quest for common origins for all types of radicalism is certainly relevant yet limited. Indeed, most of the current research on radicalization, using cross-sectional and longitudinal data, analyses the occurrence of terrorism whatever its ideological orientation (Piazza, 2006, Abadie, 2006, Caruso \& Schneider, 2011, Dreher \& Fischer, 2011, Krueger, 2007, Li \& Schaub, 2004, Kis-Katos et al., 2011). However, some key variables may be missed by such analyses because they may have different causal relationships with distinct ideological orientations of radicalism. 
Indeed, there is evidence that such an interaction effect is not limited to the macro-economic variables have analysed here. Previous research has shown that some psychological dispositions that were hypothesized to underlie extremism are in fact predictive of certain ideological contents. For instance, the need to reduce threat and uncertainty, which was thought to drive all kinds of extremism (e.g. Hogg, Meehan \& Farquharson, 2010), is in fact related to right-wing ideologies (Jost et al., 2003, Jost et al., 2007) and right-wing radicalization in particular (Rieger et al., 2017, Pauwels \& Heylen, 2017, Frischlich et al., 2015). Similarly, research indicates that there are substantial socio-demographic differences between left-wing and right-wing activists (Chermak \& Gruenewald, 2014), suggesting that research should focus on the individual determinants of right-wing versus left-wing radicalization. In other words, the current difficulties in finding general determinants of radicalization may be due to the fact that the concept of radicalization incorporates phenomena that future research should disaggregate into distinct radical ideologies. Secondly, the present study demonstrates the relevance of system-justification theory (Jost et al., 2017) to explain historical occurrences of radical collective action. Until now, evidence about this topic was mostly based on survey (Osborne \& Sibley, 2013) or experimental data (Jost et al., 2012). This paper provides a first test of this theory based on the "natural" historical dynamics of collective action. The results clearly support the view that systemchallenging and system-supportive protests have different contextual origins, and that understanding the distinct psychological needs and motivations underlying political ideologies is a prerequisite to producing hypotheses on the conditions in which their adherents radicalize.

Thirdly, the results support the idea of re-integrating economic conditions in particular and macro-societal determinants in general into the explanation of social movements. Indeed, literature about social movements has mostly forsaken structural theories such as relative 
deprivation (Gurr, 2015) to focus on theories of resource mobilization, political opportunity structure or micro-theory of frame processes (Walder, 2009). The present analysis proves that macro determinants do matter in the dynamics of social movements. This means that the mobilization capacity of social movements is not only dependent on the political entrepreneurs' ability to communicate but also on macro contexts that make some discourses inherently more attractive to potential recruits.

\subsection{Limitations and future direction}

This study has two kinds of limitations: relative to the data itself and relative to the design of the test. The dataset is first limited in its historical and geographical scope, thus limiting historical and cross-sectional generalization. Also, I could not totally eliminate potential problems of representativeness and reliability. Although I controlled for the most obvious factors of over/under-representation (decade, ideology and organization type) which could produce incorrect generalization, representativeness biases remained irreducible since we do not know the characteristics of the overall population of radical organizations. Furthermore, whilst the method used limited reliability biases, the reliability of the sources remains questionable since there is no comparable measure on the study period to test for convergent validity. Future research should ascertain whether the results are replicated based on other cases and cross-national comparisons.

Secondly, the study design provides no empirical cues to determine the individual-level causal mechanism. A crucial question is whether collective deprivation affects individual radicalization through the perception of a collective threat or through individual experience of deprivation. The literature suggests a socio-tropic mechanism. Indeed, a core finding from the relative deprivation literature is that whilst group relative deprivation may foster collective action in some circumstances, individual relative deprivation only predicts individual behaviour - such as stealing or using drugs (Smith, Pettigrew, Pippin \& Bialosiewicz, 2012). 
Besides, research on ideology indicates that collective economic threat is related to increased authoritarianism while individual deprivation is not (Feldman \& Stenner, 1997).

\section{[Insert table 2 around here]}

Finally, due to the contemporary relevance of Islamist radicalism (Shughart, 2006), it is worth ascertaining whether the present theoretical framework may contribute to disentangling this phenomenon. There are good reasons to expect that it will, as Islamist radical ideologies share various traits that could be defined as reactionary (Moghadam, 2009). As presented in table 2, when looking at indicators of wealth and inequality in Western societies, the theory presented clearly aligns with the global trend of radicalism and the rise of Islamist radicalism (Shughart, 2006): specifically the transition from left-wing oriented terrorism in the 1960s and 1970s, in times of economic progress, to reactionary terrorism through both right-wing and Islamist movements in the 1990s to the present day, following periods of economic stagnation and the rise of inequality. This historical pattern seems consistent with the theory but deserves a rigorous empirical examination.

\section{References}

Abadie, A. (2006). Poverty, political freedom, and the roots of terrorism. American Economic Review, 96(2), 50-56.

Caruso, R., \& Schneider, F. (2011). The socio-economic determinants of terrorism and political violence in Western Europe (1994-2007). European Journal of Political Economy, 27, S37-S49.

Chermak, S., \& Gruenewald, J. A. (2015). Laying a foundation for the criminological examination of right-wing, left-wing, and Al Qaeda-inspired extremism in the United States. Terrorism and Political Violence, 27(1), 133-159.

Collier, P., \& Hoeffler, A. (1998). On economic causes of civil war. Oxford Economic Papers, 50(4), 563-573. 
Della Porta, D. (2006). Social movements, political violence, and the state: A comparative analysis of Italy and Germany. Cambridge University Press.

Doty, R. M., Peterson, B. E., \& Winter, D. G. (1991). Threat and authoritarianism in the United States, 1978-1987. Journal of Personality and Social Psychology, 61(4), 629.

Dreher, A., \& Fischer, J. A. V. (2011). Does government decentralization reduce domestic terror? An empirical test. Economics Letters, 111(3), 223-225.

Duckitt, J., \& Fisher, K. (2003). The impact of social threat on worldview and ideological attitudes. Political Psychology, 24(1), 199-222.

Feldman, S., \& Stenner, K. (1997). Perceived threat and authoritarianism. Political Psychology, 18(4), 741-770.

Frischlich, L., Rieger, D., Hein, M., \& Bente, G. (2015). Dying the right-way? Interest in and perceived persuasiveness of parochial extremist propaganda increases after mortality salience. Frontiers in Psychology, 6.

Funke, M., Schularick, M., \& Trebesch, C. (2016). Going to extremes: Politics after financial crises, 1870-2014. European Economic Review, 88, 227-260.

Gurr, T. R. (2015). Why men rebel. Routledge.

Hogg, M. A., Meehan, C., \& Farquharson, J. (2010). The solace of radicalism: Selfuncertainty and group identification in the face of threat. Journal of Experimental Social Psychology, 46(6), 1061-1066.

Jost, J. T. (2017). Ideological Asymmetries and the Essence of Political Psychology. Political Psychology, 38(2), 167-208.

Jost, J. T., Becker, J., Osborne, D., \& Badaan, V. (2017). Missing in (Collective) Action: Ideology, System Justification, and the Motivational Antecedents of Two Types of Protest Behavior. Current Directions in Psychological Science, 26(2), 99-108. 
Jost, J. T., Chaikalis-Petritsis, V., Abrams, D., Sidanius, J., Van Der Toorn, J., \& Bratt, C. (2012). Why men (and women) do and don't rebel: Effects of system justification on willingness to protest. Personality and Social Psychology Bulletin, 38(2), 197-208. Jost, J. T., Glaser, J., Kruglanski, A. W., \& Sulloway, F. J. (2003). Political conservatism as motivated social cognition. Psychological Bulletin, 129(3), 339-375.

Jost, J. T., Napier, J. L., Thorisdottir, H., Gosling, S. D., Palfai, T. P., \& Ostafin, B. (2007). Are needs to manage uncertainty and threat associated with political conservatism or ideological extremity? Personality and social psychology bulletin, 33(7), 989-1007. Kis-Katos, K., Liebert, H., \& Schulze, G. G. (2011). On the origin of domestic and international terrorism. European Journal of Political Economy, 27, S17-S36.

Krieger, T., \& Meierrieks, D. (2011). What causes terrorism? Public Choice, 147(1), 3-27. Krueger, A. B. (2007). What makes a terrorist. Economics and the roots of terrorism. Princeton University Press.

Kurrild-Klitgaard, P., Justesen, M. K., \& Klemmensen, R. (2006). The political economy of freedom, democracy and transnational terrorism. Public Choice, 128(1-2), 289-315. Li, Q., \& Schaub, D. (2004). Economic globalization and transnational terrorism: A pooled time-series analysis. Journal of Conflict Resolution, 48(2), 230-258.

Lipset, S. M., \& Raab, E. (1970). The politics of unreason: right wing extremism in America, 1790-1970 (Vol. 5). Harper \& Row.

Marx, K., \& Engels, F. (2002). The communist manifesto. Penguin.

Miller, S. V. (2017). Economic Threats or Societal Turmoil? Understanding Preferences for Authoritarian Political Systems. Political Behavior, 39(2), 457-478.

Moghadam, A. (2009). Motives for martyrdom: Al-Qaida, Salafi Jihad, and the spread of suicide attacks. International Security, 33(3), 46-78. 
Moskalenko, S., \& McCauley, C. (2009). Measuring political mobilization: The distinction between activism and radicalism. Terrorism and Political Violence, 21(2), 239-260.

Onraet, E., Van Hiel, A., \& Cornelis, I. (2013a). Threat and Right-Wing Attitudes: A CrossNational Approach. Political Psychology, 34(5), 791-803.

Onraet, E., Van Hiel, A., Dhont, K., \& Pattyn, S. (2013b). Internal and External Threat in Relationship With Right-Wing Attitudes. Journal of Personality, 81(3), 233-248.

Osborne, D., \& Sibley, C. G. (2013). Through rose-colored glasses: System-justifying beliefs dampen the effects of relative deprivation on well-being and political mobilization.

Personality and Social Psychology Bulletin, 39(8), 991-1004.

Parker, C. S., \& Barreto, M. A. (2014). Change they can't believe in: The Tea Party and reactionary politics in America. Princeton University Press.

Pauwels, L. J., \& Heylen, B. (2017). Perceived Group Threat, Perceived Injustice, and SelfReported Right-Wing Violence: An Integrative Approach to the Explanation Right-Wing Violence. Journal of Interpersonal Violence, $0(0), 1-27$.

Piazza, J. A. (2006). Rooted in poverty?: Terrorism, poor economic development, and social cleavages 1. Terrorism and Political Violence, 18(1), 159-177.

Pigenet, M., \& Tartakowsky, D. (2014). Histoire des mouvements sociaux en France: De 1814 à nos jours. La Découverte.

Piketty, T. (2013). Le capital au XXIe siècle. Le Seuil.

Polity IV (2013), [Data file]. Retrieved from (http://www.systemicpeace.org/inscrdata.html). Rickert, E. J. (1998). Authoritarianism and economic threat: Implications for political behavior. Political Psychology, 19(4), 707-720.

Rieger, D., Frischlich, L., \& Bente, G. (2017). Propaganda in an insecure, unstructured world: How psychological uncertainty and authoritarian attitudes shape the evaluation of right-wing extremist internet propaganda. Journal for Deradicalization, (10), 203-229. 
Sales, S. M. (1972). Economic threat as a determinant of conversion rates in authoritarian and nonauthoritarian churches. Journal of Personality and Social Psychology, 23(3), 420.

Sales, S. M. (1973). Threat as a factor in authoritarianism: An analysis of archival data. Journal of Personality and Social Psychology, 28(1), 44.

Shughart, W. F. (2006). An analytical history of terrorism, 1945-2000. Public Choice, 128(1), $7-39$.

Smith, H. J., Pettigrew, T. F., Pippin, G. M., \& Bialosiewicz, S. (2012). Relative deprivation: A theoretical and meta-analytic review. Personality and Social Psychology Review, 16(3), $203-232$.

Tausch, N., Becker, J. C., Spears, R., Christ, O., Saab, R., Singh, P., \& Siddiqui, R. N. (2011). Explaining radical group behavior: Developing emotion and efficacy routes to normative and nonnormative collective action. Journal of Personality and Social Psychology, 101(1), 129. The Maddison-Project (2013), [Data file]. Retrieved from (http://www.ggdc.net/maddison/maddison-project/home.htm).

Walder, A. G. (2009). Political sociology and social movements. Annual review of sociology, $35,393-412$.

\section{Figures and tables}




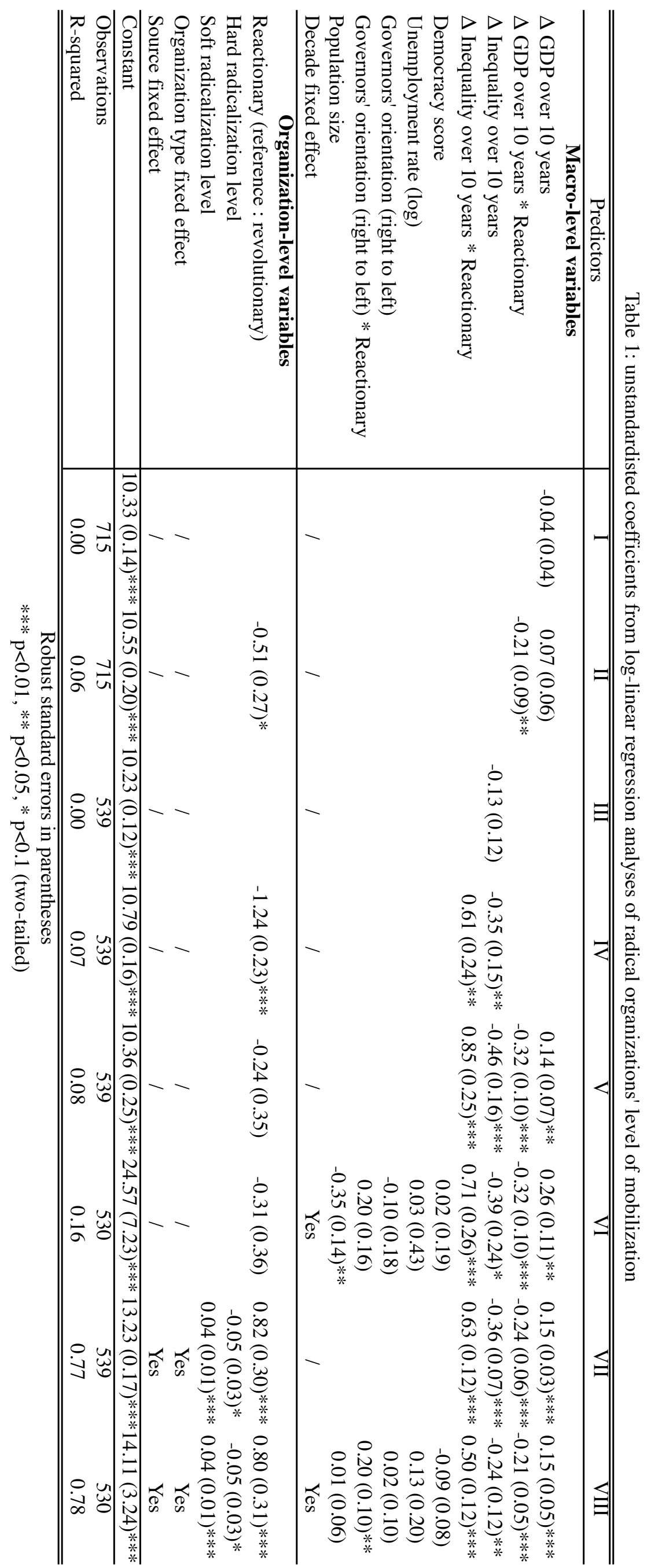


Table 2: global trends of terrorism and collective economic deprivation in Western societies

\begin{tabular}{c|cc}
\hline \hline & $1960-1979$ & $1990-2009$ \\
\hline Main ideological orientation of terrorism & Revolutionary & Reactionary \\
& Left-wing groups & Islamist / right-wing groups \\
Annual growth of the GDP per capita & High-rate & Low-rate \\
& $+3.3 \%$ & $+1.5 \%$ \\
Annual growth of inequality & Decreasing & Increasing \\
& $-1.3 \%$ & $+1.5 \%$ \\
\hline \hline
\end{tabular}

See the detail of the calculations of the economic indicators in the online appendix.

Figure 1: Predictive margins of the mobilization level of radical organizations with $95 \% \mathrm{Cls}$

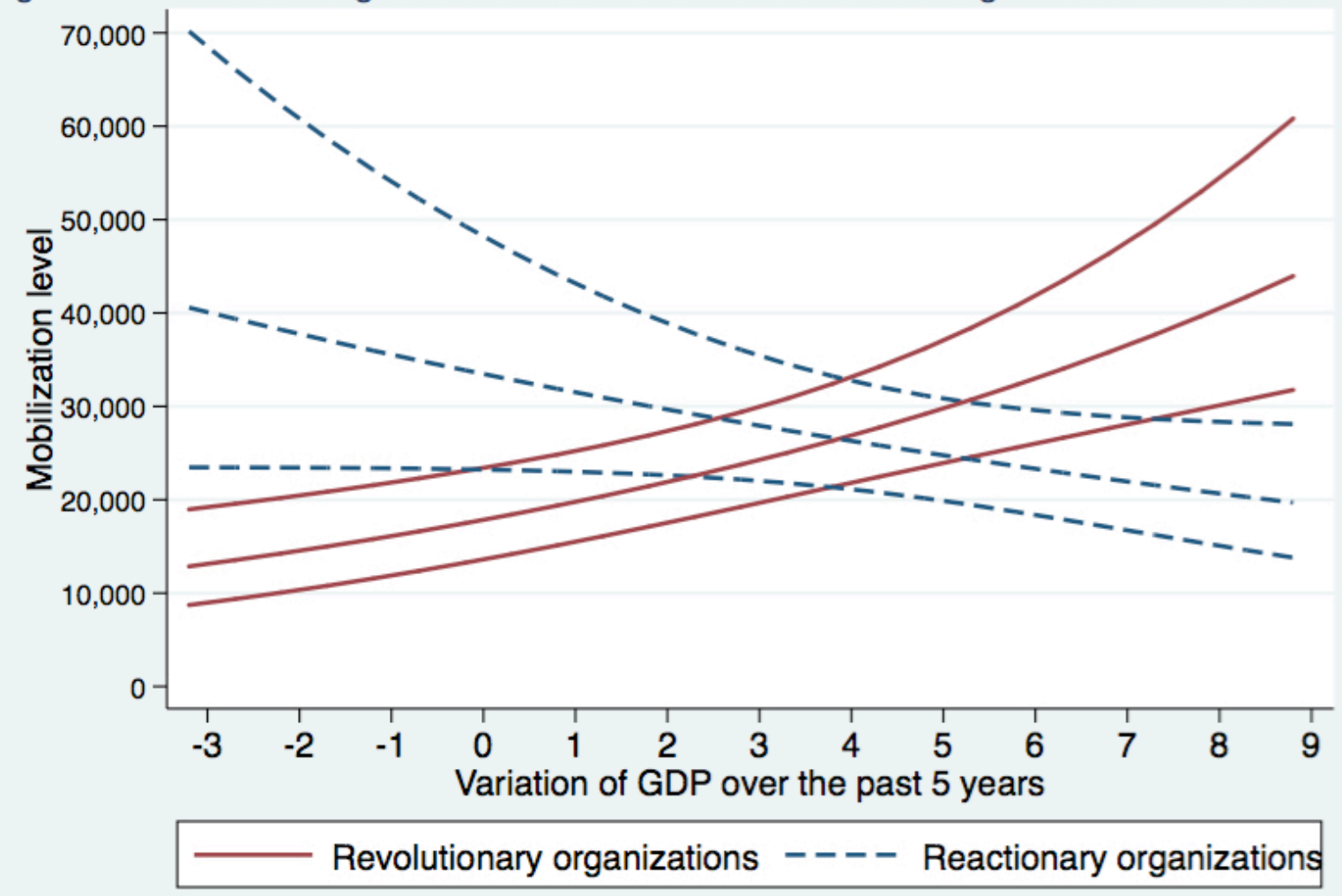


Figure 2: Predictive margins of the mobilization level of radical organizations with $95 \% \mathrm{Cls}$

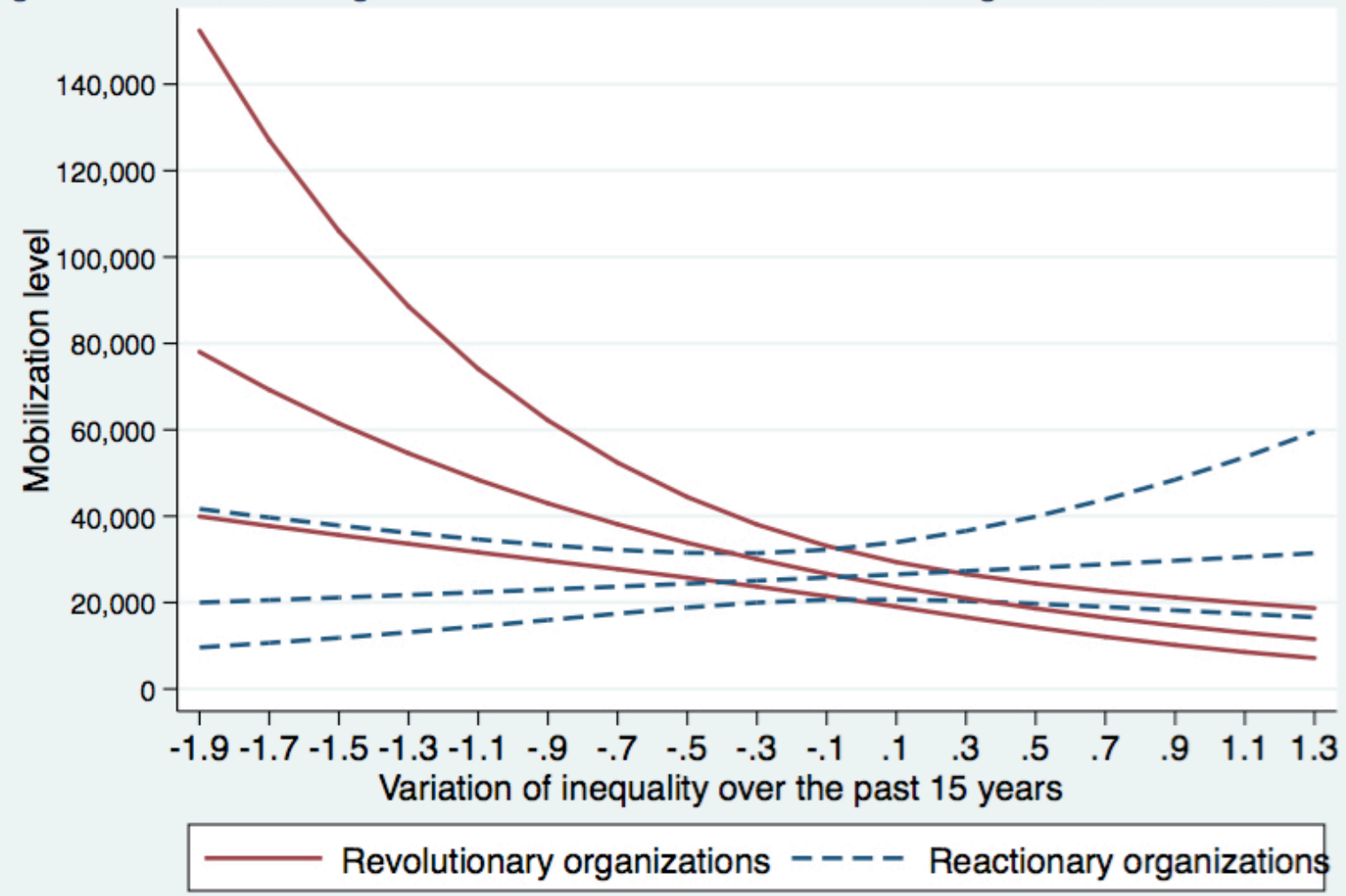

